
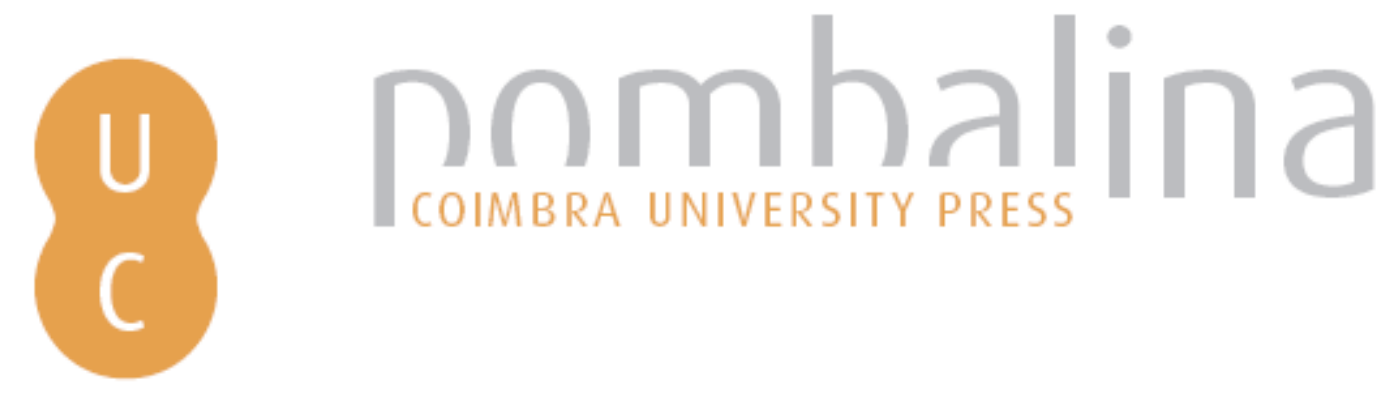

\title{
Addressing trade-offs among fuel management scenarios through a dynamic and spatial integrated approach for enhanced decision-making in eucalyptus forest
}

\begin{tabular}{|c|c|}
\hline Autor(es): & $\begin{array}{l}\text { Botequim, Brigite; Ager, Alan; Pacheco, Abílio P.; Oliveira, Tiago; Claro, } \\
\text { Joao; Fernandes, Paulo M.; Borges, José G. }\end{array}$ \\
\hline Publicado por: & Imprensa da Universidade de Coimbra \\
\hline $\begin{array}{l}\text { URL } \\
\text { persistente: }\end{array}$ & URI:http://hdl.handle.net/10316.2/34166 \\
\hline DOI: & DOI:http://dx.doi.org/10.14195/978-989-26-0884-6_178 \\
\hline Accessed : & 26-Apr-2023 11:47:46 \\
\hline
\end{tabular}

A navegação consulta e descarregamento dos títulos inseridos nas Bibliotecas Digitais UC Digitalis, UC Pombalina e UC Impactum, pressupõem a aceitação plena e sem reservas dos Termos e Condições de Uso destas Bibliotecas Digitais, disponíveis em https://digitalis.uc.pt/pt-pt/termos.

Conforme exposto nos referidos Termos e Condições de Uso, o descarregamento de títulos de acesso restrito requer uma licença válida de autorização devendo o utilizador aceder ao(s) documento(s) a partir de um endereço de IP da instituição detentora da supramencionada licença.

Ao utilizador é apenas permitido o descarregamento para uso pessoal, pelo que o emprego do(s) título(s) descarregado(s) para outro fim, designadamente comercial, carece de autorização do respetivo autor ou editor da obra.

Na medida em que todas as obras da UC Digitalis se encontram protegidas pelo Código do Direito de Autor e Direitos Conexos e demais legislação aplicável, toda a cópia, parcial ou total, deste documento, nos casos em que é legalmente admitida, deverá conter ou fazer-se acompanhar por este aviso.

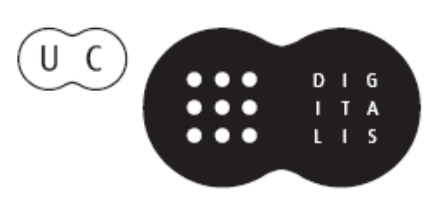




\section{ADVANCES IN}

Forest Fire

\section{RESEARCH}

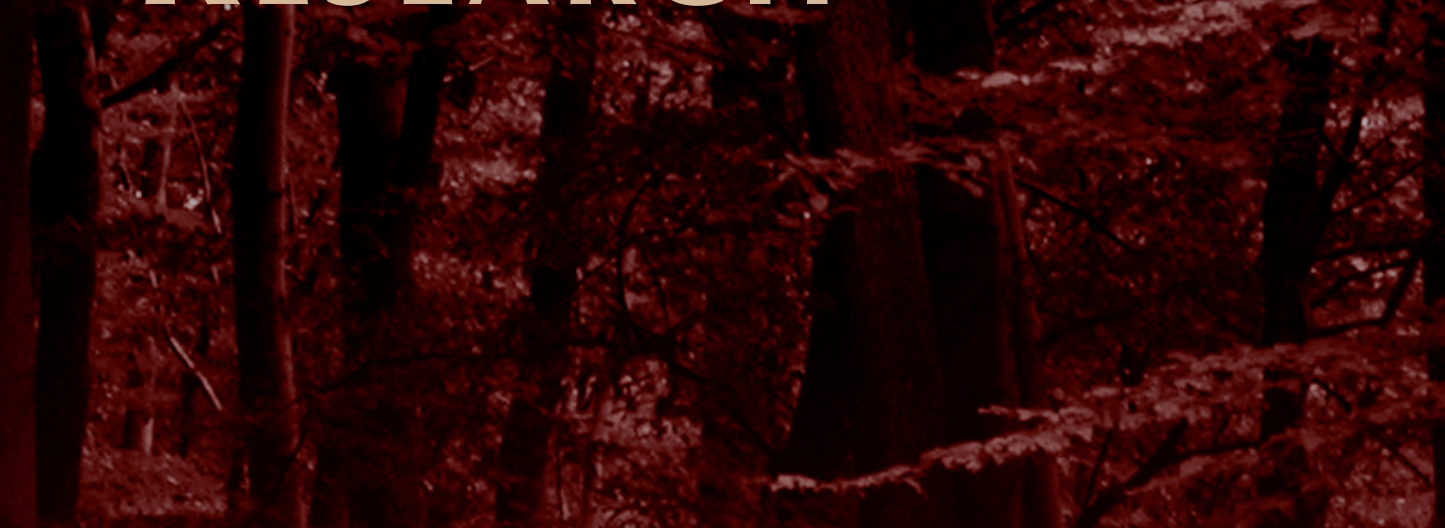

\section{DOMINGOS XAVIER VIEGAS}

\section{EDITOR}




\title{
Addressing trade-offs among fuel management scenarios through a dynamic and spatial integrated approach for enhanced decision-making in eucalyptus forest
}

\author{
Brigite Botequim ${ }^{a *}$, Alan Ager ${ }^{b}$, Abílio P. Pacheco ${ }^{c}$, Tiago Oliveira ${ }^{\mathrm{d}}$, Joao Claro ${ }^{\mathrm{c}}$, Paulo M. \\ Fernandes $^{\mathrm{e}}$, José G. Borges ${ }^{\mathrm{a}}$ \\ ${ }^{a}$ Departamento de Recursos Naturais, Ambiente e Território, Instituto Superior de Agronomia \\ (ISA),Universidade de Lisboa, Tapada da Ajuda, 1349-017 Lisboa, Portugal. \\ *bbotequim@isa.ulisboa.pt,joseborges@isa.ulisboa.pt \\ ${ }^{b}$ USDA Forest Service, Pacific Northwest Research Station, Western Wildland Environmental \\ Threat Assessment Center, 3160 NE 3rd Street, Prineville, OR 97754,USA. aager@fs.fed.us \\ ${ }^{c}$ INESC TEC (INESC Porto) and Faculdade de Engenharia, Universidade do porto, Campus da \\ FEUP, Rua Dr. Roberto Frias, 378, 4200-465 Porto, Portugal.abilio.p.pacheco@inescporto.pt, \\ jclaro@fe.up.pt \\ ${ }^{d}$ Forest Protection, grupo Portucel Soporcel(gPS), Edifício Mitrena, Apartado 55, 2091-861 \\ Setúbal, Portugal.tiago.oliveira@portucelsoporcel.com \\ ${ }^{e}$ Centre for the Research and Technology of Agro-Environmental and Biological Sciences (CITAB), \\ University of Trás-os-Montes e Alto Douro, Quinta de Prados, 5001-801 Vila Real, Portugal. \\ pfern@utad.pt
}

\begin{abstract}
Addressing sustainability concerns in Mediterranean forest ecosystems management with the growing incidence of fires impacting the forest areas over the past decades is a complex task. The current framework was driven taking into account several decision support tools of the United States Wildfire Modeling System for wildfire risk management, which focuses on a three-tiered approach strategy calibrated and applied in Portugal. In addition, contains spatial and temporal dimensions to integrate landscape-scale properties required to meet fire management goals, without encroaching budget constraints, while meeting demands for timber values. Explicitly : i) Developing and applying a Forest System Dynamic Model for identifying temporal stand-scale and understory fuel dynamics, including a site and regional percentage of burnt probability; ii) Building for each landscapes fuel population distribution the expected fire behaviour curve trends, i.e. the corresponding spread rate and flame length using EXRATE tool and FlamMap simulator, respectively, thereby allowing the calculation of changes in the annual expected wood loss; iii) Spatially optimize in the Landscape Treatment Designer tool (LTD) the location of fuel treatments distribution. For testing and demonstration purposes, the research considered an application encompassing three properties of pulp mill's from the Grupo Portucel Soporcel (gPS) in the North, Central and South of Portugal, where eucalypt (E. globulus) is predominant (extent $\approx 3665 \mathrm{ha}$ ). A sensitivity analysis was performed by measuring trade-offs among specific treatment scenarios: "treated" vs "untreated" or "treated considering neighbors". The effect of each scenario was changed by a set percentage of optimal parameters and a series of LTD runs was recorded as a project. The protection of the eucalyptus trees from potential wildfires loss was assumed as a key primary goal, following by a set of quantitative target stand structures, budgets and policies constraints in proportion of area treated, and fire behaviour thresholds for each farm. Parameters decisions were assessed to address the identification of thresholds for radical change in fire behavior, and further insight to support hazard-reduction fuel practices. The accuracy of the results demonstrates the usefulness and relevance of the pursued to calculate the potential effect of treatments strategies on improving fire resiliency. Further, the approach provided an overview of management guidelines for fuel modifications to make the gPS eucalyptus farms in Portuguese conditions more resistant to fire, selecting priority intervention areas and designing effective strategies.
\end{abstract}

Keywords: Forest System dynamic Model; Fire behavior; Spread rate; budget constraints; Landscape Treatment Designer; Fuel management strategies. 


\section{Introduction}

About $35.4 \%$ of the area of Portugal is covered by forest. Nonetheless in the Mediterranean and in Portugal the forest composition is strongly determined by wildfires. Indeed, is the smallest country in southern Europe but has the highest fire incidence in the region. The management of such ecosystems sustaining the forest ecological base, in a changing physical, socio-economic, cultural, demographic and political context is a challenge. Thus, fires should be taken into account when developing forest management plans. We have little or no control over most factors in the fire behavior triangles. However, one element we can control is the common denominator - fuel. Indeed, fire risk and wildfire damage can be reduced by removing or reducing fuels in strategic locations. Fuel structure and flammability are primary conditions for fire spread (Pausas and Paula 2012) and fuel treatments have been found to decrease wildfire size (e.g. Baeza and Vallejo 2008; Rideout et al. 2008; Boer et al. 2009). Fuel treatment positively affects suppression efforts by reducing fire spread and fire intensity (Rideout et al. 2008). Thus, the emphasis today in forest management is on forest restoration and fuels reduction. Nevertheless, there is an urgent need for decision support tools to enable effective fire management.

Where to treat? How much? Shape and size? In this sense, for handling with the complexity of such forest management problems that wildfire risk implies for forest owners and policy-makers, the present research try to answer the above-mentioned questions focusing on techniques for address the problem of spatially optimize treatments to prioritize fuel management activities, aimed at disrupt fire spread and protect eucalyptus areas from burning without have loss of important ecological and commercial timber values. For that purpose, a Forest System Dynamic Model have been developed and coupled with spatial optimization software (Landscape Treatment Designer - LTD, Ager et al. 2012) to design efficient landscape fuel treatment plans.

The current framework includes a three-tiered approach strategy such as i) developing a Forest System Dynamic Model; ii) Characterizing the expected fire behaviour characteristics (e.g. spread rate and flame length); iii) Explore the optimal levels of fuel landscape treatment configurations in the LTD tool. The pursued are tested and results are discussed for a large-scale application encompassing over 3365 ha of eucalyptus in North, Centre and Southern Portugal.

\section{Methods}

The framework presented here was based on an extensive literature review (e.g. Finney 2003; Alan et al. 2013), field work to assign fuel model distribution, and analysis of a database within three Eucalyptus farms located in the North (1471, 48 ha), Centre (173, 34 ha) and South region (2020, 34 ha) from the Grupo Portucel Soporcel (gPS), a European company dedicated to produce and market high quality paper for office and offset uses (Figure 1). Inventory data represent conditions of the year 2013 in the study area. 


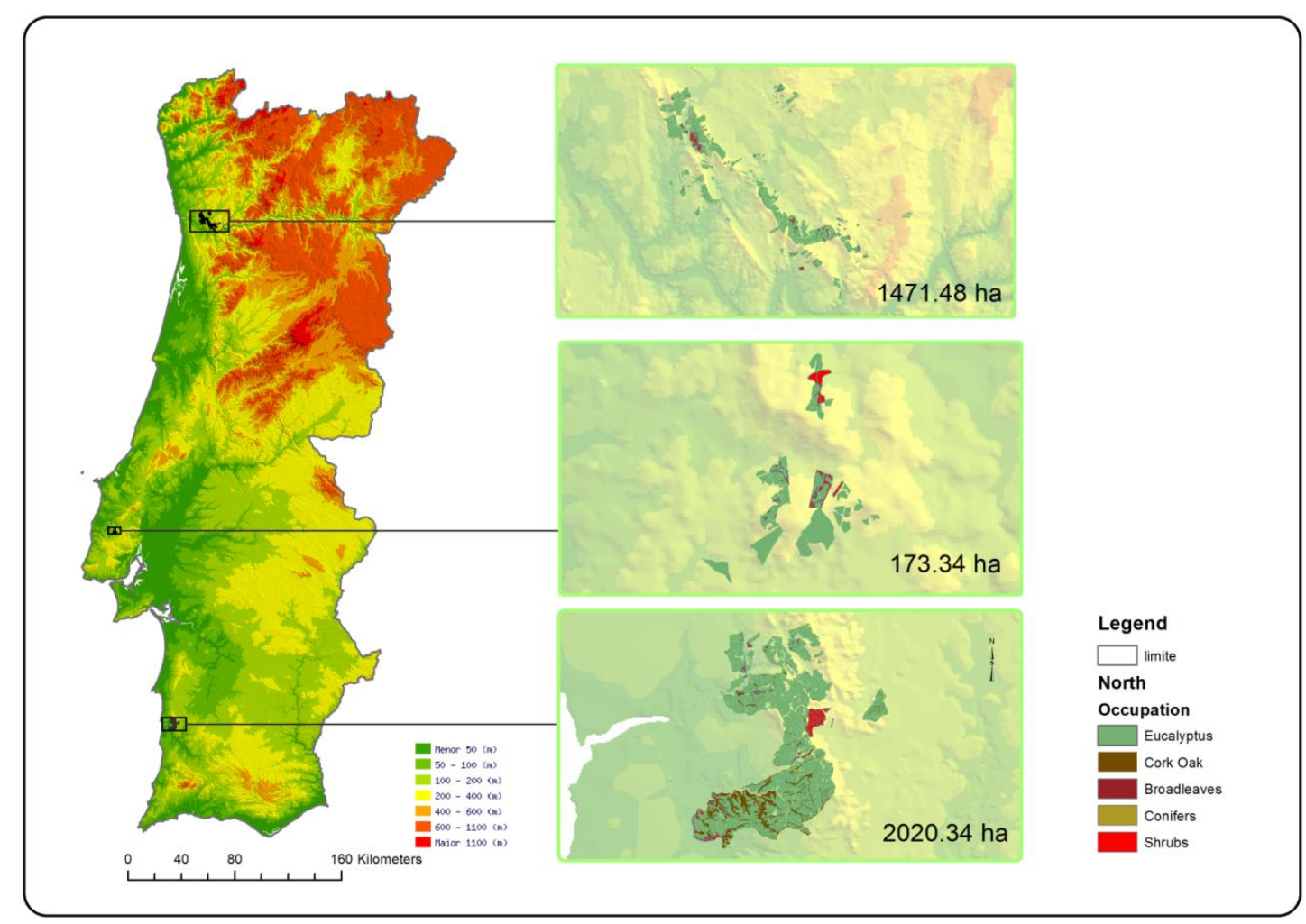

Figure 1. Portugal: location and cover types of the three farms from the Grupo Portucel Soporcel

\subsection{Developing a Forest System Dynamic Model}

In order to identify temporal trends for guiding LTD, a Forest System Dynamic Model (FSDM) was developed to examine stand-scale and fuel dynamics. The model incorporates both well-defined, quantitative field data and qualitative expert gPS opinion. Note that all the spatial fuel types under eucalyptus cover were collected "in loco" and assessed by the field guide-fuel from Project Vesta (Cheney et al. 1998; Gould et al. 2007). Further, enumerated using a set of customized fuel models developed for eucalyptus stands in Portugal (Fernandes et al. 2009). Such dynamic model was used to classify fuel over time due to planting operations, harvesting, and vegetation regrowth.

In addition, an estimate of total burnt probabilities (TBP, \%) on each eucalyptus farm was also integrated in the model as a "burnt factor" based on landscape and site scale wildfire modelling information available in Portugal. In the former, each stand burns considering an adjusted burnt probability based on the regional fire frequency analysis (Oliveira et al. 2012) and the fire regimes at the municipality-level obtained by multiple correspondence analysis and spatial clustering (Pereira $e t$ al. submitted). For the site-scale the probability of wildfire occurrence in Eucalyptus stands was calculated by Botequim et al. (2013). Furthermore, wildfire impacts and resulting damage over time at stand and tree level across the eucalyptus farms was include using Marques et al. (2012) post- fire mortality equations. Thus, landscape data were generated for random mixtures of several fuel types in various proportions over time and replicated because of expected variation in weather scenarios (increase the number of additional fuel configurations).

\subsection{Characterizing the expected fire behaviour characteristics}

Current fire behavior characteristics for each stand, i.e. spread rate (SR, $\mathrm{m} / \mathrm{min}$ ) and flame length (FL, $\mathrm{m}$ ) for randomness of the fuel arrangements was calculated on the program EX-RATE (Finney 2003) and FlamMap simulator (Finney 2006), respectively. Each fuel configuration has a well-defined maximum spread rate (minimum travel time algorithm, Finney 2003). Different spread rate ratios show a sigmoid trend over the range of proportions of fuel populations. These outputs can be used to estimate 
the change in the annual expected timber loss (TL), as well to demonstrate reductions in the $\Delta \mathrm{SR}$ and $\Delta \mathrm{FL}$ from the effect of fuel treatments, to further aid in spatial allocation of fuel strategies across the eucalypt farms.

\subsection{Explore the optimal levels of fuel landscape treatments}

Spatial data for each farm indicating: (i) potential fire behavior as represented by SR and FL, (ii) expected TL in the stand for both treat and untreated conditions (iii) stand area (ha), (iv) biometric patterns such as crown base height (CBH), crown bulk density (CBD), type of fuel model (shrub or litter) for predicting fire activity (Botequim et al. in preparation); and (v) annual budget capacity for gPS fire management, was created to explore in LTD tool (Ager et al. 2012) the optimal levels of fuel landscape treatment configurations.

The protection of the eucalyptus trees from potential wildfires loss was assumed as primary goal, i.e. minimize the total predicted expected TL and maximize delta SR. Activity constraints on policy and annual budget restrictions to represent the total treatment allowance (area, ha) for fire management were considered. Thresholds were measured by potential FL, and a set of biometric patterns for each eucalypt stands.

In addition, to better understand how expected loss was affected by the above treatment parameters a sensitivity analysis using several LTD simulations was performed across all the stands in response to different investment levels, treatment intensity. The trade-offs associated with these divergent management strategies including percentage of treated and untreated areas to calculate potential mortality to eucalyptus trees were quantified to examine change in risk on improving fire resiliency.

\section{Results}

The current work expands the application in fuel spatial optimization for eucalyptus stands, and demonstrates a decision support approach computationally feasible to address the most fire-prone areas in each region and prioritize fuel management efforts based on respective management goals. The model seeks to locate project areas to most efficiently reduce potential wildfire loss of fire resilient eucalyptus trees while creating contiguous areas within which managed fire can be effectively used to maintain low-hazard conditions. Indeed, the approach identifies the aggregate of polygons that minimize the expected timber loss $\mathrm{E}(\mathrm{TL})$, and maximize the delta Spread rate $(\Delta \mathrm{SR})$ objectives, and the polygons that require treatment, i.e. the percentage of stand - treatment densities optimal in terms of the overall reduction in the potential wildfire mortality. Furthermore, the sensitivity analyses based on a series of test landscapes allows the identification of investment trade-offs with easily interpretable results. Finally, this research have real implications for spatial strategies of fuel treatments on gPS farms, and can contribute to enhance the coordination of seasonal budget for fire prevention, directing their actions to the most susceptible areas in case of extreme, and uncontrollable, weather events.

\section{Acknowledgment}

This work was financed by the European Regional Development Fund (ERDF) through the COMPETE Programme (Operational Programme for Competitiveness), by National Funds through the Fundação para a Ciência e a Tecnologia (FCT, Portuguese Foundation for Science and Technology) within projects «FCOMP - 01-0124-FEDER-037281» and «FIRE-ENGINE - Flexible Design of Forest Fire Management Systems/MIT/FSE/0064/2009», in the scope of the MIT Portugal Program, and by grupo Portucel Soporcel. FCT has also supported the research performed by Brigite Roxo Botequim (Grant SFRH/BD/44830/2008) and by Abílio P. Pacheco (Grant SFRH/BD/92602/2013). 


\section{References}

Ager AA, N. Vaillant DE, Owens S, Brittain JH (2012) Overview and example application of the Landscape Treatment Designer. PNWGTR- 859. USDA Forest Service, Pacific Northwest Research Station, Portland, Oregon, USA.

Ager AA, Vaillant, NM, McMahan A (2013) Restoration of fire in managed forests: a model to prioritize landscapes and analyze tradeoffs. Ecosphere 4:art29.

Baeza MJ, Vallejo VR (2008) Vegetation recovery after fuel management in Mediterranean shrublands. Appied Vegetation Science 11:151-158.

Boer MM, Sadler RJ, Wittkuhn RS, McCaw L, Grierson PF (2009) Long-term impacts of prescribed burning on regional extent and incidence of wildfires e evidence from 50 years of active fire management in SW Australian forests. Forest Ecology and Management 259, 132-142

Botequim B, Garcia-Gonzalo J, Marques S, Ricardo A, Borges JG, Oliveira MM, Tomé J, Tomé M (2013). Developing wildfire risk probability models for Eucalyptus globulus stands in Portugal. iForest 6:217-227. doi: 10.3832/ifor0821-006.

Botequim B, Fernandes PM, Garcia-Gonzalo J, Silva A, Borges J. Modeling fire behavior and risk in Portuguese's forest: guidelines for sustainable landscape management (unpublished data).

Cheney NP, Gould JS, McCaw L (1998) Project Vesta: research initiative into the

effects of fuel structure and fuel load on behaviour of wildfires in dry eucalypt forest. In: Proceedings 13th International Conference of Forest Fire and Meteorology. International Association of Wildland Fire, pp. 375-378.

Cheney NP, Gould JS, McCaw L, Anderson WR (2012) Predicting fire behaviour in dry eucalypt forest in Southern Australia. Forest Ecology and Management 280,120-131.

Fernandes P, Gonçalves H, Loureiro C, Fernandes M, Costa T, Cruz M, Botelho 2009. Modelos de combustível florestal para Portugal. Proceedings Congresso Florestal Nacional, Açores.

Finney M (2003) Calculation of fire spread across random landscapes. International Journal of Wildland Fire 12, 167-174.

Finney M (2006) An overview of FlamMap fire modeling capabilities. In: Andrews PL, Butler BW (eds) Fuels management-how to measure success:conference proceedings.RMRS-P-41. USDA Forest Service, Rocky Mountain Research Station,Portland, pp 213-220.

Gould JS, McCaw WL, Cheney NP, Ellis PE, Knight IK, Sullivan AL (2007) Project Vesta. Fire in Dry Eucalypt Forest: Fuel Structure, Fuel Dynamics, and Fire Behaviour. Ensis-CSIRO, Canberra, ACT and Department of Environment and Conservation, Perth, WA, Australia.

Marques S, Garcia-Gonzalo J, Borges JG, Botequim B, Oliveira MM, Tomé J, Tomé M (2011) Developing post-fire Eucalyptus globulus Labill stand damage and tree mortality models for enhanced forest planning in Portugal. Silva Fennica 45 (1): 69-83. ISSN 0037-5330.

Oliveira S, Pereira JMC, Carreiras JMB (2012). Fire frequency analysis in Portugal (1975-2005), using Landsat-based burnt area maps. International Journal of Wildland Fire 21,48-60.

Rideout DB, Ziesler P, Kling R, John B, Loomis R, Botti SJ (2008). Estimating rates of substitution for protecting values at risk for initial attack planning and budgeting. Forest Policy and Economics 10, 205-219. 


\title{
Analysis of burnt areas and number of forest fires in the Iberian Peninsula
}

\author{
Marta M. Mato ${ }^{\mathrm{c}}$, José Luis Legido ${ }^{\mathrm{c}}$, Eva Miguez ${ }^{\mathrm{c}}$, Vicente Caselles ${ }^{\mathrm{d}}$, Eulogio Jiménez ${ }^{\mathrm{e}}$, Tarsy \\ Carballas $^{\mathrm{b}}$, Maria I. Paz Andrade ${ }^{\mathrm{a}}$
}

${ }^{a}$ Departamento de Física Aplicada, Microcalorimetría, Facultad de Física, Universidade de Santiago de Compostela, Campus Universitario Sur, E-15782 Santiago de Compostela, Spain, inmaculada.paz.andrade@usc.es

${ }^{b}$ Instituto de Investigaciones Agrobiológicas de Galicia (IIAG-CSIC), Campus Universitario Sur, Apartado 122, E-15780 Santiago de Compostela, Spain, tcf@iiag.csic.es

${ }^{c}$ Departamento de Física Aplicada, Universidade de Vigo, Vigo, Spain, xllegido@uvigo.es

${ }^{d}$ Departamento de Física de la Tierra y Termodinámica, Universidad de Valencia, Valencia, Spain, vicente.caselles@uv.es

${ }^{e}$ Departamento de Física, Universidade de A Coruña, A Coruña, Spain, ejimenez@udc.es

\begin{abstract}
The Iberian peninsula has suffered for many years from large scale forest fires, which in the past decades have been devastating for all components of the environment: destruction of biological systems, loss of organic matter from soils and alteration of atmospheric and climatic processes.

In this study we analyse the variation in number and burnt areas in the Iberian Peninsula (Portugal and Spain), using mathematical functions. The results obtained are compared with other European Mediterranean countries such as France, Italy and Greece. More than 1.5 million fires were recorded in the Mediterranean countries between 1980 and 2011, involving a burnt area of approximately 15 million hectares, where $67 \%$ of the fires and $60 \%$ of the burnt area lay in the Iberian Peninsula. Upon using the adjustment functions, the evolution of the number of fires in the Iberian Peninsula shows a growth rate between 1980 and 2000, while a decline in fires was observed after 2001. There is a continuous decrease in burnt area throughout these years.

The evolution of the number of fires in Spain and Portugal presents a behaviour that is quite similar to that in the Mediterranean countries. However, this is not true for the burnt areas, where an increase in Spain from 1980 to1985 was observed, and this decreased after 1986. Portugal on the other hand presents an increase in burnt areas from 1985 to 2003.
\end{abstract}

Keywords: Iberian peninsula, burnt areas, number of forest fire, mathematical function

\section{Introduction}

Spain like Portugal and other Mediterranean countries are suffering the dramatic consequences of the forest fires, which in the last years have produced a big deforestation that provokes degradation of the environment and important socio-economical losses. Their direct destructive effects are manifested in all components of the environment: the vast forest area burnt (forest and scrub); the destruction of the fauna; the loss of soil organic matter, with the consequent variation of all its properties and the loss of soil quality; and altering atmospheric and climatic processes due to particles and smoke released by the fire, which also contains hydrocarbons, greenhouse gases and toxic substances for humans and animals In addition, there are indirect effects caused by the destruction of the vegetation cover, which leaves the soil unprotected against the impact of the rain, and subsequent post-fire erosion, producing the drag of the finest components of topsoil (seeds, organic and inorganic substances) necessary for normal development of the vegetation, and in extreme conditions, the irreversible loss of soil and even the rock outcrop. The drag of water and sediments caused by the erosion and deposition away from the fire epicenter will alter aquatic and marine ecosystems and habitat for fish, shellfish, etc. This has 